\title{
The Konde Country
}

\section{Author(s): Dr. Merensky}

Source: The Geographical Journal, Vol. 2, No. 4 (Oct., 1893), pp. 321-323

Published by: geographicalj

Stable URL: http://www.jstor.org/stable/1773915

Accessed: 27-06-2016 03:05 UTC

\section{Your use of the JSTOR archive indicates your acceptance of the Terms \& Conditions of Use, available at}

http://about.jstor.org/terms

JSTOR is a not-for-profit service that helps scholars, researchers, and students discover, use, and build upon a wide range of content in a trusted digital archive. We use information technology and tools to increase productivity and facilitate new forms of scholarship. For more information about JSTOR, please contact support@jstor.org.

The Royal Geographical Society (with the Institute of British Geographers), Wiley are collaborating with JSTOR to digitize, preserve and extend access to The Geographical Journal 


\section{THE KONDE COUNTRY.*}

By the Rev. Dr. MERENSKY.

IN 1891 the Rev. Dr. Merensky, of the Berlin Missionary Society, conducted a party of missionaries to the Konde country, at the northern end of Lake Nyasa. They reached the lake by way of the Zambesi and Shire; started from Karonga on September 29th, and founded the station Wangewannshöh on October 2nd. Dr. Merensky describes the water of Lake Nyasa as being clear and of agreeable taste. At its northern end the lake is shallow, and abounds in sandbanks, due to the immense masses of débris carried into it by six large rivers. The southern portion of the lake is much deeper, and in places no bottom has been reached at a depth of 200 fathoms. Dr. Merensky maintains that the lake has not changed its level for thousands of years. There is an annual rise, due to the rains, but the difference between the highest level, in April and May, and the lowest, in November or December, scarcely exceeds 3 feet. As a proof that no material change in the lakelevel has taken place for ages, Dr. Merensky points to the clearly-marked beach-lines on Monkey Bay, the highest of which, in August, was only 2 feet $4 \frac{1}{2}$ inches above the then

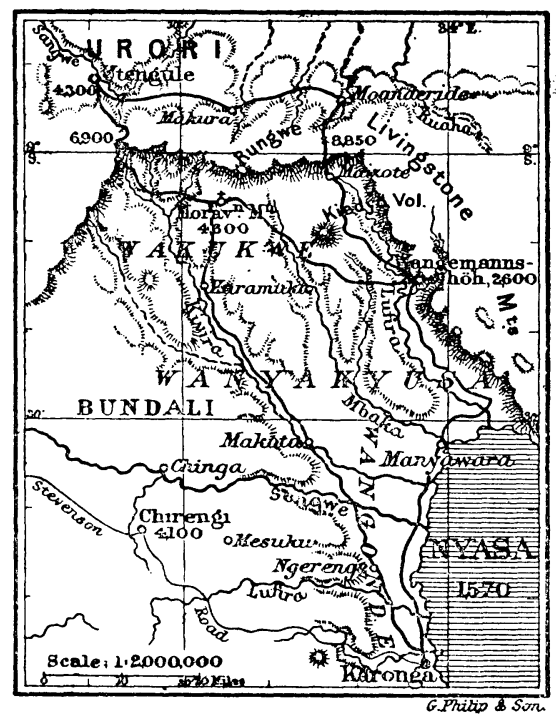

level of the lake. He found, moreover, that huge Adansonias, having a diameter of between 10 and 15 feet, grew only a few feet above the edge of the water at Mponde, at Livingstonia, and in Leopolds Bay. According to Adanson, the age of a tree of such dimensions would be about five thousand years. The permanency of the lake-level is explained by the existence of a ledge of granite which crosses the Shire about 30 miles below the Molomba Lake. Above this barrier the current of the Shire is very sluggish, and this accounts for the gradual silting-up of the small lake just named.

* Report of Paper read at the meeting of the Berlin Geographical Society, July 8th, 1893.

No. IV.-October, 1893.] 
The banks of the Nyasa in the south, south-east, and west, are anything but attractive. Barren, rocky mountains here and there approach the edge of the water, or are separated from it by swamps. The soil is little productive and often sandy. There is a remarkable absence of rivers. On the other hand, the land lying to the north-east and east of the lake, although it presents fewer facilities for commercial intercourse with the interior, is distinguished for its beauty and fertility. The Konde country is shut in by the steep slopes of the Livingstone Mountains, which rise to a height of 10,000 feet. These mountains consist of ancient crystalline rocks, quartzite, hornblende, gneiss, and magnetite. Their steep slopes are almost bare of vegetation, although forests of deciduous trees are not altogether wanting on the slopes facing the lake. Higher up we meet with bamboo thickets, whilst the northern slopes, descending towards the Ruaha, are more abundantly wooded. Within the amphitheatre formed by these mountains, in the centre of the Konde country, there rises the Kiedyo, an extinct volcano, with a crater-lake, cinder beds, and streams of basaltic lava, whilst the forest-clad Rungwe (10,000 feet) forms a buttress of the encircling mountain range on the north.

The Konde country covers an area of about 2000 square miles. It is traversed by six large rivers, fed by numerous springs and rivulets. Of these rivers the Songwe separates the British from the German territory, whilst the Kivira, Mbaka, and Lufira are within the latter.

The country towards the mountains is hilly, but the district bordering the lake consists in the main of a dead flat, flooded for months in the summer, and habitable only in a few localities which rise above its general level. The soil in the hills is a heavy loam. The fertility of the country is due to the distribution of the rainfall. The following are the results of meteorological observations, made at Wangemannshöh in 1892 :-

\begin{tabular}{|c|c|c|c|c|c|c|}
\hline & & & & ean Temperature. & & \\
\hline & & & & Fabrenheit. & Inches. & Days. \\
\hline January . & . & . & . & $75 \cdot 7^{\circ}$ & $8 \cdot 78$ & 23 \\
\hline February & . & . & . & $74 \cdot 7^{\circ}$ & $14 \cdot 57$ & 21 \\
\hline March . & . & . & . & $72 \cdot 0^{\circ}$ & $6 \cdot 10$ & 21 \\
\hline April. & . & . & & $71 \cdot 2^{\circ}$ & $8 \cdot 31$ & 18 \\
\hline May. & . & . & . & $69 \cdot 6^{\circ}$ & $1 \cdot 10$ & 5 \\
\hline June . & . & . & . & $67 \cdot 6^{\circ}$ & $\cdot 39$ & 5 \\
\hline July . . & . & . & . & $66 \cdot 6^{\circ}$ & $1 \cdot 14$ & 11 \\
\hline August . & . & . & . & $68 \cdot 9^{\circ}$ & $\cdot 24$ & 2 \\
\hline September & . & . & . & $73 \cdot 4^{\circ}$ & $\cdot 00$ & 0 \\
\hline October. & . & . & . & $77 \cdot 4^{\circ}$ & $\cdot 08$ & 1 \\
\hline November & & . & . & $78 \cdot 6^{\circ}$ & $1 \cdot 06$ & 11 \\
\hline December & - & - & - & $74 \cdot 3^{\circ}$ & $7 \cdot 20$ & 20 \\
\hline $\mathrm{Ye}$ & & . & . & $72 \cdot 5^{\circ}$ & $48 \cdot 97$ & 138 \\
\hline
\end{tabular}

Violent winds are almost unknown to the west of the Livingstone 
Mountains, and this circumstance greatly favours the cultivation of bananas, seven varieties of which are known in the country.

The game is not very varied. Elephants are still occasionally met with in the swamps, as also herds of buffaloes; but hippopotami are numerous, and crocodiles much dreaded. Of other game only zebras and eland antelopes are met with, and that rarely, owing to the dense population.

The people known as Wakonde (Wangonde) really belong to three clans, viz., the Wangonde, around Karonga; the Wanyakyusa, in the centre; and the Wakukwe, towards Mount Rungwe. Linguistically they belong to the family of the Maganja (Anyanjaor Anyasa), which occupies the whole of the country from the Zambesi to the Livingstone Mountains. In the east and west these tribes have been encroached upon by Angoni and Ayawa (Yao). Altogether they number about 100,000 souls. They are more nearly related to the Warori and the Mambwe than to the tribes to the south of the Zambesi. They have occupied their present seats for ages, but are traditionally supposed to have come from the east. They have in a remarkable manner utilised the natural resources of their country. They cultivate Indian bamboos and thus obtain an excellent material for building their houses and stables. Agriculture, and the breeding of hump-backed cattle, are carried on with much success. The disposition of the people is gentle, and we hear nothing of the cruelties so often practised in other parts of Africa. The cleanliness of the houses and village streets is quite remarkable. Trees are planted for ornamental purposes. The tribal government is carried on on liberal principles, and there are no despotic chiefs. Woman is accorded a high position, and legally quite the equal of man. The great defect in the character of the people is thievishness, but among this peaceably disposed people this rarely leads to murder. On the other hand, suicides are rather frequent.

\section{CASIMIR MAISTRE'S JOURNEY FROM THE CONGO TO THE SHARI AND BENUE.*}

IN the country lying at the back of the German sphere of "Camarons" and between the Rivers Congo, Shari and Benue, which not many years ago appeared as a blank upon our maps, French explorers have recently exhibited a persistent activity deserving of all praise. 'They have been more successful in opening up new countries and solving geographical problems than their German competitors, and whether this is ultimately

* Comptes Rendus of the Paris Geographical Society, 1893, p. 269, with map. 